\title{
PENGARUH SUHU PADA PEMBENTUKAN \\ PRECIPITATED CALCIUM CARBONATE (PCC) MELALUI \\ METODA KAUSTIK SODA DENGAN MENGGUNAKAN \\ PELARUT ASAM KLORIDA
}

\author{
Budi Hermawan, Syukri Arief dan Novesar Jamarun \\ Laboratorium Anorganik, Jurusan Kimia, FMIPA Universitas Andalas, Padang
}

\begin{abstract}
Precipitated Calcium Carbonate (PCC) is the limestone product resulting from certain process steps. By XRF measurement it has found that the content of $\mathrm{CaO}$ (oxide calcium) in limestone Bukit Tui Padang Panjang as follows 54.19\%, $\mathrm{SiO}_{2} 1.03 \%, \mathrm{Al}_{2} \mathrm{O}_{3} 0.39 \%, \mathrm{MgO} 0.46 \%$ and $\mathrm{Fe}_{2} \mathrm{O}_{3} 0.2 \%$. Rendemen PCC at optimum concentration of $0.75 \mathrm{M} \mathrm{HCl}$ is $69.77 \%$. The formation of PCC by using the highest PCC rendemen aquabides is $9.28 \%$ at optimum temperature of $50^{\circ} \mathrm{C}$. With 0.75 $\mathrm{M} \mathrm{HCl}$, the highest rendemen is $79.32 \%$ at optimum temperature $70^{\circ} \mathrm{C}$. The formation of crystals in the form vaterite, aragonite and calcite were evidenced by X-ray Diffraction (XRD). Treatment with $2.00 \mathrm{M} \mathrm{HCl}$ at $30^{\circ} \mathrm{C}$ showed the formation of vaterite $(45.83 \%)$, aragonite $(35.93 \%)$ and calcite $(18.24 \%)$ with crystals size of $28.43 \mathrm{~nm}$. In the other case, preparation with $0.75 \mathrm{M} \mathrm{HCl}$ at $30^{\circ} \mathrm{C}$ resulting the percentage of vaterite and aragonite which were $73.01 \%$ and $26.99 \%$ respectively fairished $28.06 \mathrm{~nm}$. Then for the one which were treated with $0.75 \mathrm{M} \mathrm{HCl}$ at $70^{\circ} \mathrm{C}$ indicated the formation of vaterite $(75.53 \%)$ fairished $33.68 \mathrm{~nm}$ and aragonite $(24.47 \%)$. SEM (Scanning Electron Microscopy) towards the sample prepared from $0.75 \mathrm{M} \mathrm{HCl}$ at $30^{\circ} \mathrm{C}$ have clearly shown that the particle sphere fairished at $3.68 \mathrm{~nm}$ where the one treated with $0.75 \mathrm{M} \mathrm{HCl}$ at $70^{\circ} \mathrm{C}$ having particle sphere fairished at $3.3 \mu \mathrm{m}$ showing needle like estimated of $3.8 \mu \mathrm{m}$.
\end{abstract}

Keywords : Precipitated Calcium Carbonate (PCC), caustic soda method

\section{DAFTAR PUSTAKA}

1. Dinas Pertambangan, Potensi Bahan Galian Sumatera Barat, 2006.

2. J. P. Sibilia, A Guide to Materials Characterization and Chemical Analysis, Second Edition, Mc Graw-Hill, USA, 1996.

3. Yulfitrin, Pembuatan Precipitated Calcium Carbonate (PCC) dari batu kapur dengan metoda kaustik soda modifikasi, Padang, 2007.

4. M. Azis, Kalsium Karbonat, Karakteristik serta Penggunaannya dalam Industri, Makalah Teknik No. 3 tahun 6, 1997.

5. J. W. Ahn, Manufacture of aragonite Precipitated Calcium Carbonate by a Carbonation Process Using Dust from a stainless Refining sludge Plant in POSCO, J. Ceramic Processing Research, 3(2): $62-65,(2004)$.
6. O. Bowles, Limestone and Dolomite, Bureau of Mines, L.C. California, 1965, 252.

7. J. G. Bush, Determinative Mineralogy and Blow and Blow Pype Analisis, Jhon Wiley \& Sons, Champman and Hall, 1998, 289.

8. A. Muchtar, dan S. Nuryadi, Pilot Plant pembuatan kalsium karbonat presipitat (PCC).

9. T. Listerand and J. Renshaw, Understanding Chemistry Second Edition, Stanley Thornes Publishers Ltd, England, 1995.

10. Vogel, Text Book of Macro and Semimicro Qualitative Inorganic Analysis, Logman group Limited, London, 1997.

11. D. A. Skoog, Principles of Instrumental Analysis, $3^{\text {rd }}$ ed, Soanders Collage Publishing, USA, 1985. 
